\section{Social geography of AIDS in Brazil: identifying patterns of regional inequalities}

\author{
Geografia social da AIDS no Brasil: identificando \\ padrões de desigualdades regionais
}

\author{
Geografía social del SIDA en Brasil: los patrones \\ de identificación de las desigualdades regionales
}

Tatiana Rodrigues de Araujo Teixeira 1 Renata Gracie 2 Monica Siqueira Malta 1 Francisco I. Bastos 2
1 Escola Nacional de Saúde Pública Sergio Arouca Fundação Oswaldo Cruz, Rio de Janeiro, Brasil.

2 Instituto de Comunicação

e Informação Científica e Tecnológica em Saúde, Fundação Oswaldo Cruz, Rio de Janeiro, Brasil.

Correspondence

T. R. A. Teixeira

Escola Nacional de Saúde Pública Sergio Arouca Fundação Oswaldo Cruz. Rua dos Artistas 161, apto. 201, Rio de Janeiro, $R J$ 20541-035, Brasil. tatirodriguesaraujo@yahoo. com.br

\begin{abstract}
The trend towards decline and stabilization of the AIDS epidemic in Brazil should be analyzed carefully, since aggregate data can mask regional or local inequalities in such a large and diverse country. The current study reevaluates the epidemic's spatial dissemination and the AIDS-related mortality pattern in Brazil. The study considered all AIDS cases diagnosed in individuals over 18 years of age and living in Brazil, as well as AIDS deaths recorded in 1998-2008. Threeyear moving average rates were estimated, and a spatial analysis was conducted using a local empirical Bayesian method. The epidemic was only found to be expanding in the North and Northeast regions, while declining in the rest of the country, especially in the Southeast. According to the findings, the apparent stabilization of AIDS mortality tends to mask regional disparities. Social determinants of health and regional disparities should be taken into account in program development and policymaking.
\end{abstract}

Acquired Immunodeficiency Syndrome; Spatial Analysis; Ecological Studies

\section{Resumo}

A tendência ao declínio e estabilização da epidemia de AIDS no Brasil deve ser analisada de forma criteriosa, uma vez que, num país de grande extensão territorial e diversidade, dados agregados podem mascarar desigualdades regionais ou locais. Este estudo reavalia a difusão espacial da epidemia e o padrão de mortalidade secundária à AIDS no Brasil. Foram considerados todos os casos diagnosticados em maiores de 18 anos, residentes no país, bem como os óbitos registrados em 1998-2008. Foram estimadas taxas médias móveis trienais e realizada análise espacial com auxílio do método bayesiano empírico local. Verificou-se que a epidemia encontrava-se em expansão apenas no Norte e Nordeste, enquanto declinava no restante do país, acentuadamente no Sudeste. Os achados mostram que a aparente estabilização da mortalidade por AIDS tende a mascarar disparidades regionais. Os determinantes sociais da saúde e disparidades regionais devem ser levadas em conta na formulação de programas e políticas.

Síndrome de Imunodeficiência Adquirida; Análise Espacial; Estudos Ecológicos 


\section{Introduction}

According to recent estimates by the Joint United Nations Programme on HIV/AIDS (UNAIDS) in late 2011, there were 34 million (31.4-35.9 million) persons living with HIV/AIDS in the world. The most recent UNAIDS report showed a reduction of more than $50 \%$ in the rate of new HIV infections in 25 low and middle income countries, more than half of Africa, the region most heavily affected by the spread of HIV 1 .

Brazil has a large and extremely heterogeneous territory, with the AIDS epidemic concentrated in certain regions and subpopulations. The epidemic's apparent homogeneity and stability mask a complex situation with localized epidemic processes affecting certain regions and/ or populations at greater risk 2 .

From 1980 to June 2012, 656,701 new AIDS cases were reported in Brazil 3. In the last year, the incidence rate in the country varied from 19.6 to 20.2 cases $/ 100,000$ inhabitants. The South was the region of the country with the highest AIDS incidence, with 30.9 cases/100.000 inhabitants, followed by lower rates in the Southeast (21.0), North (20.8), Central-West (17.5), and Northeast (13.9) ${ }^{3}$.

The largest concentration of cases occurs in the coastal cities and large metropolitan areas $4,5,6,7$. The epidemic remains concentrated in the large cities, and the shift inland is characterized by small or medium rises and falls in discontinuous case reporting, displaying a heterogeneous combination of stability, decline, and expansion, occurring differently in the various regions of the country 8 .

Progress in the treatment of HIV infection includes the development and use of different groups of antiretroviral drugs (nucleoside and non-nucleoside reverse transcriptase inhibitors, protease inhibitors, and more recently fusion and integrase inhibitors). The combination of these drugs in the form of defined treatment regimens based on validated clinical protocols constitutes so-called highly active antiretroviral therapy (HAART). HAART, implemented since the late 1990s, together with various prevention and control measures, resulted in important improvements in life expectancy and quality of life for persons living with HIV/AIDS in the developing countries and in marginalized populations in developed countries, with an important reduction in morbidity and mortality 9,10,11,12.

A recent study showed substantial reductions in AIDS-related adult mortality rates in Sub-Saharan Africa. The largest decreases coincided with the places where the supply of HAART was rapidly decentralized and where treatment was locally available, suggesting that decentralization and/ or attention to local specificities are essential for a policy of expanded and comprehensive access 13 .

There was a substantial improvement in prognosis for persons living with HIV/AIDS since HAART was introduced in Brazil in 1996. As of June 2012, there were some 660,000 persons living with HIV/AIDS in the country, of whom approximately 440,000 were in free clinical and laboratory follow-up under the Brazilian Unified National Health System (SUS). Of these, 220,000 thousand were using HAART. Among HAART users, $97.8 \%$ remained in treatment after 12 months and $90.5 \%$ were alive after five years of treatment 3,14 .

Evaluations of the Brazilian response to the AIDS epidemic are essential, and ecological studies of the epidemic's dynamics in Brazil, although numerous, generally lack sufficient methodological refinement, aimed at a better evaluation of the changes underway, observed empirically by clinicians and health system administrators in the context of increasingly complex epidemic with marked heterogeneity 15,16,17,18,19,20,21.

This study aims to verify the variations in spatial and temporal diffusion of the epidemic and to contribute to public policy proposals and the adoption of preventive measures to deal with the country's regional disparities.

\section{Methodology}

This ecological study aimed to evaluate the AIDS epidemic's spatial spread and mortality patterns in the post-HAART phase throughout Brazil. The analytical units were the country's 5,565 municipalities and 558 micro-regions, as defined by the Brazilian Institute of Geography and Statistics (IBGE. http://www.ibge.gov.br).

Data were used from different information systems: SINAN-AIDS (Information System on Diseases of Notification), SISCEL (Control System for Laboratory Tests), SICLOM (Logistics Control System for Medicines), and SIM (Mortality Information System). These different databases were integrated through linkage, a procedure conducted by the Ministry of Health and used in a previous study 11 .

The records resulting from the linkage were analyzed according to the adult AIDS case confirmation criterion adopted by the Department of STD/AIDS and Viral Hepatitides of the Ministry of Health: individuals 13 years or older recorded in the SISCEL/SICLOM database with a CD4+ Tlymphocyte count below 350 cells $/ \mathrm{mm}^{3} 22$.

The current study considered AIDS cases reported according to the above-mentioned AIDS 
case definition, but for individuals 18 years or older, since the object was adults (as defined by Brazil's civil and penal legislation) living with AIDS, living in the country, as well as all deaths recorded among AIDS cases, from 1998 to 2008, totaling 347,831 cases and 109,746 AIDS-related deaths.

Due to the instability of the indicators resulting from the relatively scarce nature of the events (AIDS cases and deaths) in some municipalities when the data were disaggregated, two complementary strategies were adopted: estimated temporal moving average incidence and mortality rates, using three-year means, and smoothing techniques for the variations in these indicators, taking into consideration the structure of spatial dependence and clustering of such indicators in extended time periods 23 .

The estimator defined by temporal moving averages is one way of dealing with the mean number of cases or deaths in the three-year period for each municipality and micro-region, thus obtaining stabilization of rates and thereby a reduction in their variability in the municipalities with fewer inhabitants 24 .

The local empirical Bayesian estimator is a smoothing method that estimates the rate locally by using data from geographic neighbors of the area in which one wishes to estimate the rate. The corrected rates are thus less unstable, since they take into consideration not only the information pertaining to a given area, but also that from its neighborhood 24. Hence, maps generated by Bayesian estimates allow more adequately analyzing local trends in the epidemic's spread. Calculation of the Bayesian rates used a neighborhood matrix based on the first-order criterion.

First, for the exploratory analysis and establishment of the historical series, we estimated the crude incidence and mortality rates for Brazil's five major geographic regions (North, Northeast, Southeast, South, and Central-West) and for the country as a whole. We then estimated the three-year moving averages for AIDS cases and deaths, municipalities and micro-regions, and subsequently estimated the mean incidence and mortality rates using the local empirical Bayesian method by year from 1999 to 2007. Cases and deaths from the years 1998 and 2008 were used in calculating moving averages. Populations were obtained by geometric projections of the census data from 2000 (IBGE. http://www.ibge.gov.br) and 2010. Calculation of the rates used the populations from the midpoint in each three-year period.

Calculation of the Bayesian incidence and mortality rates required excluding the municipalities and micro-regions with moving average cases and deaths equal to "zero", since the algorithm only allows calculating the Bayesian estimator in the absence of null values ("zero").

Thematic maps were constructed using digital municipal, micro-regional, and national highway grids, provided by the Geoprocessing Laboratory of the Institute of Scientific and Technological Communication and Information in Health of the Oswaldo Cruz Foundation (LabGeo - ICICT/Fiocruz).

Thematic maps were generated using the estimated Bayesian incidence and mortality rates. The cutoff points for the map classes were defined with equal intervals for the nine incidence and nine mortality maps, for both municipalities and micro-regions, in order to allow comparison of the resulting patterns. Definition of the cutoff points followed the empirical criterion of best visualization of the information on the map; various cutoff points were tested to select the ones that allowed the best epidemiological interpretation.

The municipalities and micro-regions that were excluded from the calculation of the Bayesian rates appear in the maps within the first class interval (white color) which includes the municipalities and micro-regions with rates equal to "zero".

Interactive operations between superimposed information layers were used to produce overlaying of the incidence and mortality maps with the map of Federal highways, in order to identify municipalities located along the latter.

The study was part of a larger research project: The Impact of Free and Universal Access to Antiretroviral Therapy in Brazil: Survival Analysis, approved by the Ethics Research Committee of the Sergio Arouca National School of Public Health of the Oswaldo Cruz Foundation (CEP/ ENSP/Fiocruz n. 179/08).

\section{Results}

From 1999 to 2007, 290,189 new AIDS cases were reported in Brazil. The year 2002 showed the largest number of new cases $(35,463)$, and there has been a steady decline in the number since 2003. The national incidence rate increased from 16.10 cases/100,000 inhabitants in 1999 to $20.31 / 100,000$ in 2002 , but decreased steadily beginning in 2003, from 20 cases/100,000 to 17.28/100,000 (Figure 1a).

The North and Northeast regions showed increases in incidence throughout the period, with the largest increase in the North. The CentralWest region showed an increase from 1999 to 2003, with a decline beginning only in 2004. The 
South showed an increase in the incidence rate until 2002, a decline from 2003 to 2006, and a major new upturn in 2007. Meanwhile, the Southeast showed a decline from 1999 to 2001, a new peak in 2002, and a subsequent steady decline beginning in 2003. Of the latter three regions, the Southeast showed the largest decline (Figure 1a).

The largest number of new cases between 1999 and 2007 was reported by the Southeast region, with 158,563 , followed by the South $(62,325)$, Northeast $(38,357)$, Central-West $(17,588)$, and North $(13,356)$. Therefore, although the North had the fewest new AIDS cases, it was the region with the largest increase throughout the period. The municipalities with the most new cases were São Paulo $(33,531)$ and Rio de Janeiro $(20,290)$, followed by Porto Alegre (Rio Grande do Sul), Curitiba (Paraná), Belo Horizonte (Minas Gerais), Salvador (Bahia), Brasília (Federal District), Fortaleza (Ceará), Recife (Pernambuco), and Manaus (Amazonas).

As for mortality, Brazil reported 92,089 AIDSrelated deaths from 1999 to 2007, with an increase in the mortality rate from 1999 to 2003, when it reached 6.18/100,000 inhabitants, with a decline from 2004 to 2006 and a new upturn in 2007. The rate increased from 4.38 to 6.13 deaths/100,000 inhabitants from the beginning to the end of the period. Therefore, no decline in AIDS mortality was observed for the country as a whole, although the increase was small and remained relatively stable (Figure 1b).

All the major geographic regions showed an increase in the AIDS mortality rate in all the periods, except the Southeast, which showed a decline beginning in 2004. The North showed the largest increase in the mortality rate, followed by the Northeast (Figure 1b). The Southeast recorded the most AIDS deaths $(51,710)$, with fewer deaths in the South $(19,097)$, Northeast $(11,973)$, Central-West $(5,009)$, and North $(4,302)$. The municipalities with the most AIDS deaths in the entire period were São Paulo $(10,187)$ and Rio de Janeiro $(7,187)$, followed by Porto Alegre, Salvador, Belo Horizonte, Curitiba, Recife, Belém, Brasília, and Fortaleza.

The AIDS epidemic was only expanding in the North and Northeast, while declining in the rest of the country, especially in the Southeast. Meanwhile, AIDS mortality was only declining in the Southeast, while the other regions showed increasing mortality rates.

Mapping according to municipalities using interactive operations between distinct layers showed areas with higher incidence along the main Federal highways linking the municipalities from the Southeast to those of the CentralWest and North regions. Municipalities in the
Southeast, South, and Central-West had the highest incidence rates. As for time trends, there was a steady increase in municipalities in the highest incidence bracket in the North, Northeast, and South. Recent years witnessed an even greater expansion in the epidemic in the North and Northeast and a slight drop in the number of municipalities from the other regions in the highest incidence bracket (Figure 2).

Analysis of incidence by micro-regions showed an even clearer increase in the number of micro-regions in the North and Northeast (and in the country as a whole) with higher rates in recent years, and a reduction in the number of micro-regions with higher rates in the Southeast, South, and Central-West (Figure 3).

The Southeast, South, and Central-West showed higher AIDS mortality throughout the period. However, beginning in 2002, the South showed the country's highest mortality rates, overtaking the Southeast (Figure 4). Although the Northeast and North showed the country's lowest AIDS mortality, they were the regions with the most worrisome trends. The mortality rate in the North tripled from 1999 to 2007, from 1.48 to 4.71 deaths per 100,000 inhabitants. The rate in the Northeast more than doubled, from 1.37 to 3.40 deaths per 100,000 inhabitants.

There was an increase in the micro-regions with higher AIDS mortality in recent years in the South, Central-West, and North, along with a reduction in the Southeast (Figure 5). Thus, AIDS mortality increased slightly throughout the country, except for the Southeast (which showed a decline), but the increase was less sharp in the South and Central-West. Meanwhile the North and Northeast showed an important increase in AIDS mortality throughout the period.

\section{Discussion}

Studies with a spatial analysis of AIDS in Brazil showed the State of São Paulo as a pole from which the epidemic spread, but there was a simultaneous expansion towards the country's frontier areas 16.

The early 1990s witnessed the spread of the AIDS epidemic in Brazil in a northwestern direction and towards medium-sized cities, reaching the Central-West and some States of the North, due to selective migratory flows of young male laborers towards frontier areas such as Rondônia, Roraima, and Mato Grosso 16.

From 1993 to 1996 there was a sharp increase in incidence in the South, which began to show higher incidence, next only to the Southeast but having exceeded the rates in the Central-West, 
Crude AIDS incidence and AIDS-related mortality rates per 100,000 inhabitants according to major geographic regions of Brazil, 1999-2007.

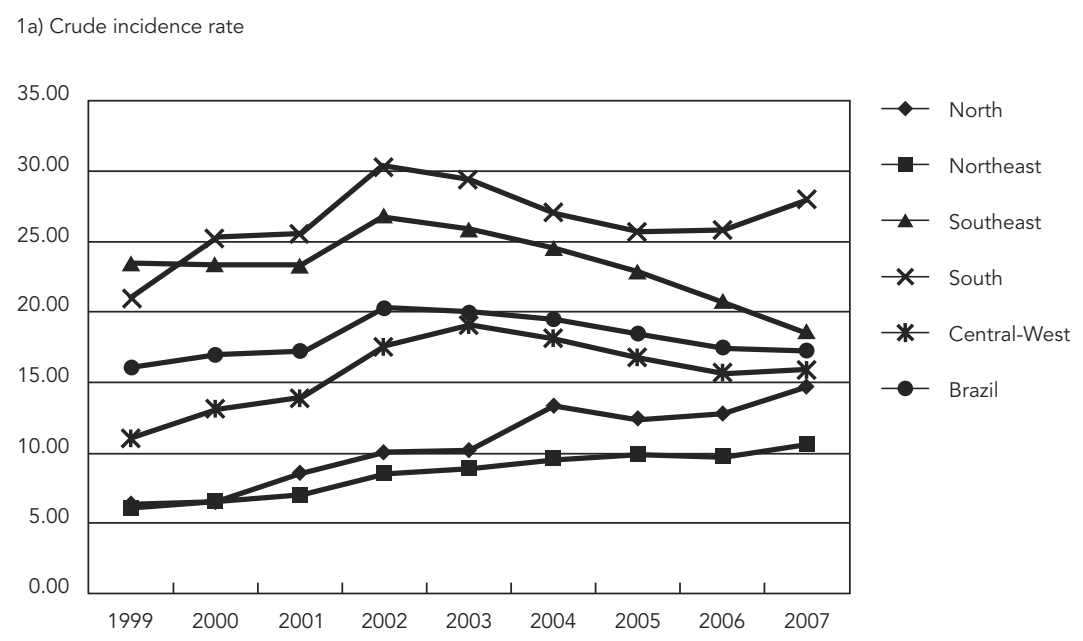

1b) Crude mortality rate

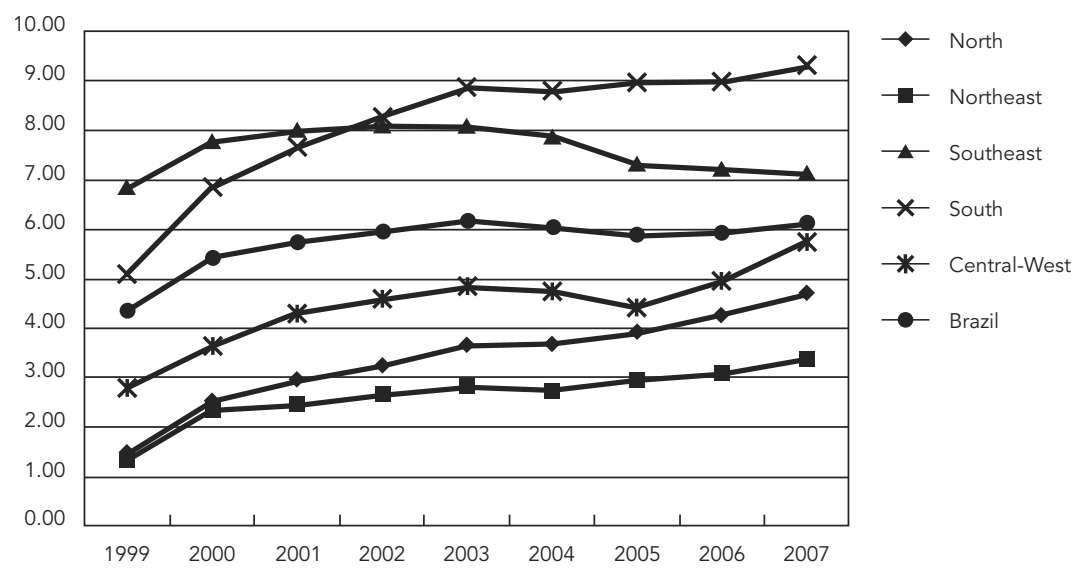

the region with the second highest incidence rate until 1992. The Southeast experienced a slower increase and a greater tendency towards stability in the epidemic. Large cities showed slower growth in the epidemic (except in the South); meanwhile, smaller cities experienced a sharp increase in incidence rates over time 18.

Some studies have pointed to temporal changes in the AIDS epidemic since 1997, following the advent of HAART. There was a trend towards stabilization of incidence rates, but the slowdown in the epidemic was not homogeneous in Brazil 25,26.
Our findings point to increases in AIDS incidence throughout the period in the North and Northeast regions of Brazil, with the largest increase in the North. The Southeast, South, and Central-West showed a decline in incidence. The epidemic was only expanding in the North and Northeast, while declining in the rest of the country, especially in the Southeast.

Furthermore, many municipalities with high incidence rates are located in areas along major Federal highways. Highways can lead to different changes in the social environment and play distinct roles in the spread and maintenance of 
Figure 2

AIDS incidence rates in Brazilian municipalities, 1999-2007.
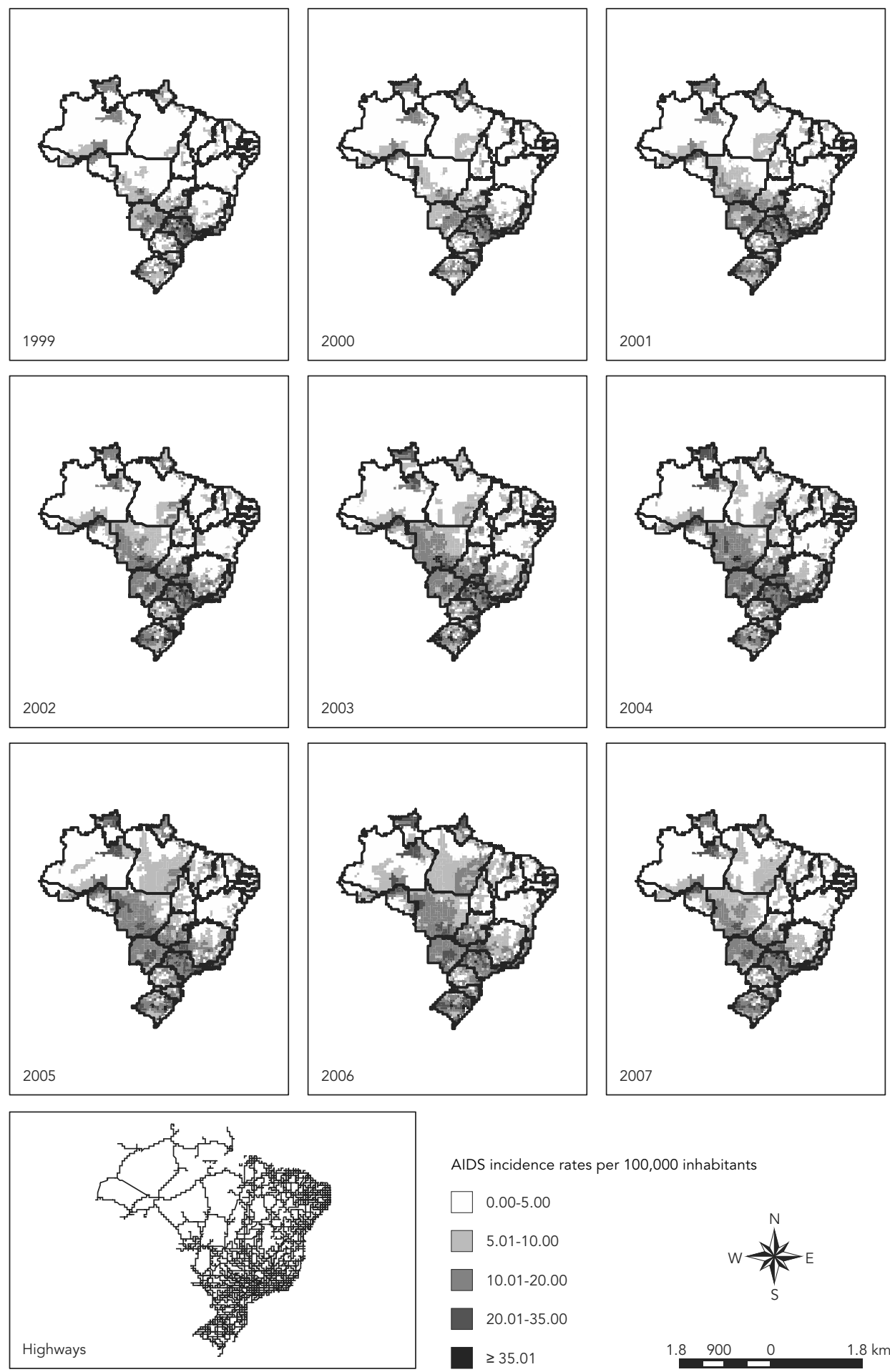

AIDS incidence rates per 100,000 inhabitants
$0.00-5.00$
$5.01-10.00$
$10.01-20.00$
$20.01-35.00$
$\geq 35.01$

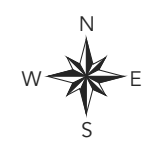

Note: data source, Information System on Diseases of Notification (SINAN. Information Technology Department of the Brazilian Unified National Health System. http://www.datasus.gov.br); geographic databases of the Brazilian Institute of Geography and Statistics (IBGE. http://www.ibge.gov.br); maps constructed by the Geoprocessing Laboratory of the Institute of Scientific and Technological Communication and Information in Health of the Oswaldo Cruz Foundation (LabGeo - ICICT/Fiocruz). 

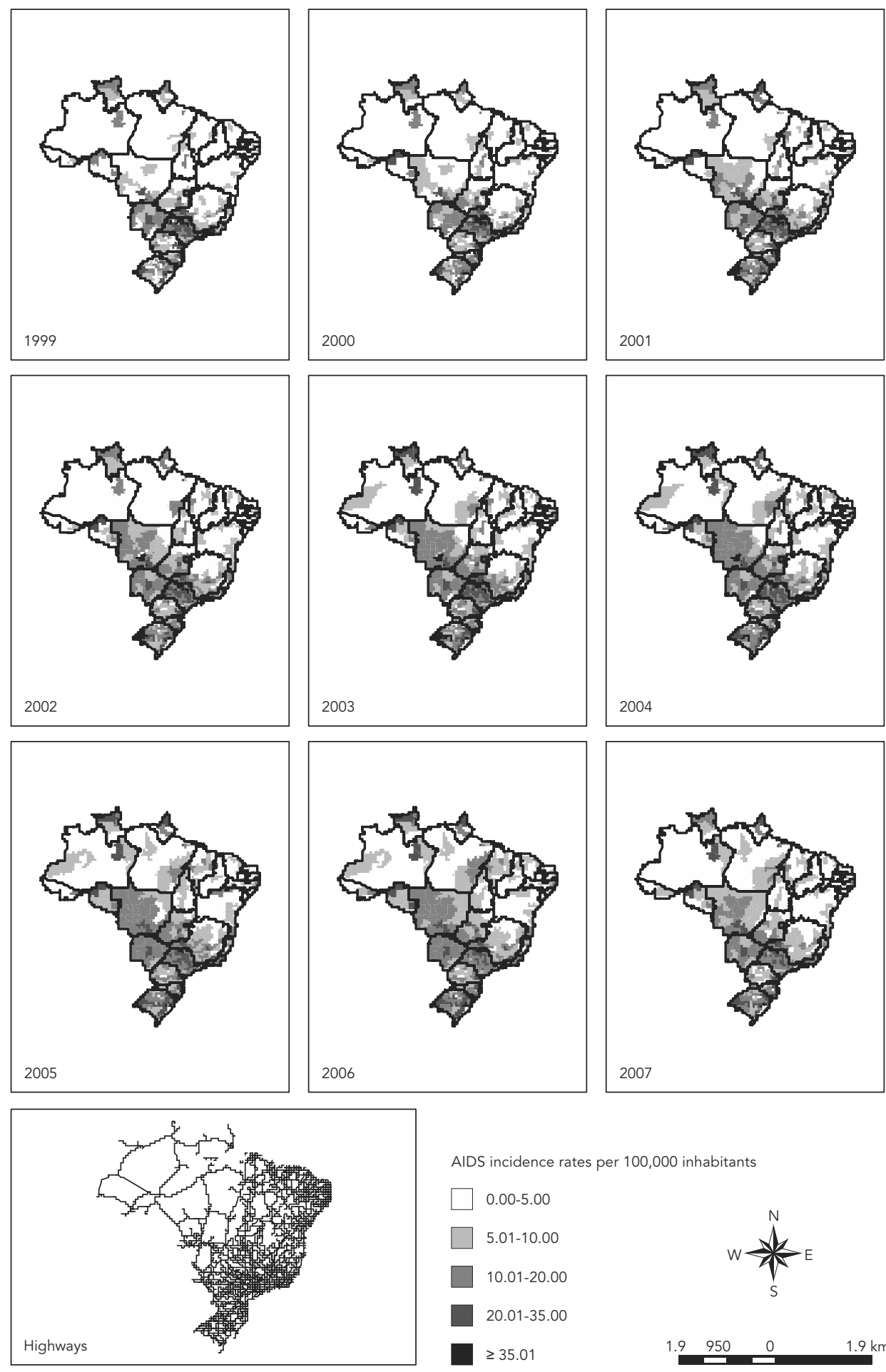

AIDS incidence rates per 100,000 inhabitants
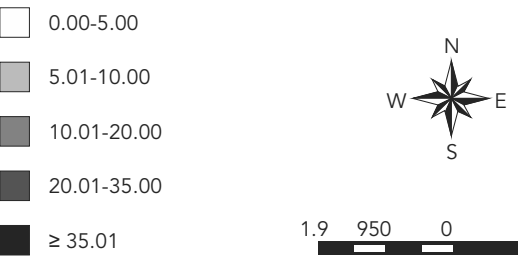

Note: data source, Information System on Diseases of Notification (SINAN. Information Technology Department of the Braziliam Unified National Health System. http://www.datasus.gov.br); geographic databases of the Brazilian Institute of Geography and Statistics (IBGE. http://www.ibge.gov.br); maps constructed by the Geoprocessing Laboratory of the Institute of Scientific and Technological Communication and Information in Health of the Oswaldo Cruz Foundation (LabGeo - ICICT/Fiocruz). 
Figure 4

AIDS-related mortality rates in Brazilian municipalities, 1999-2007.
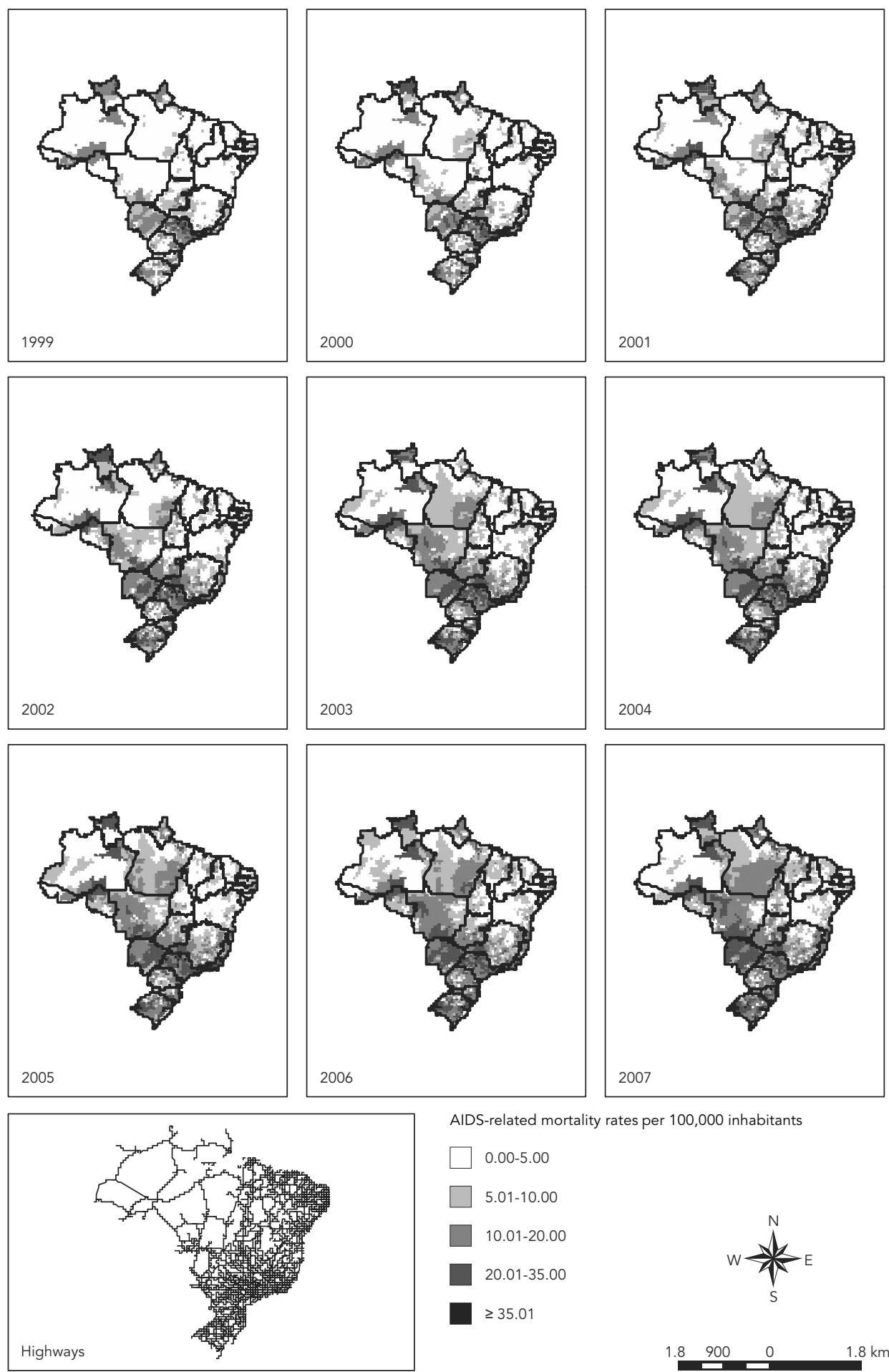

AIDS-related mortality rates per 100,000 inhabitants

$\square$ 0.00-5.00

5.01-10.00

$10.01-20.00$

20.01-35.00

$\geq 35.01$

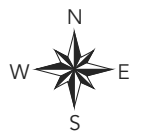

Note: data source, Information System on Diseases of Notification (SINAN. Information Technology Department of the Brazilian Unified National Health System. http://www.datasus.gov.br); geographic databases of the Brazilian Institute of Geography and Statistics (IBGE. http://www.ibge.gov.br); maps constructed by the Geoprocessing Laboratory of the Institute of Scientific and Technological Communication and Information in Health of the

Oswaldo Cruz Foundation (LabGeo - ICICT/Fiocruz). 
Figure 5

AIDS-related mortality rates in micro-regions of Brazil, 1999-2007.
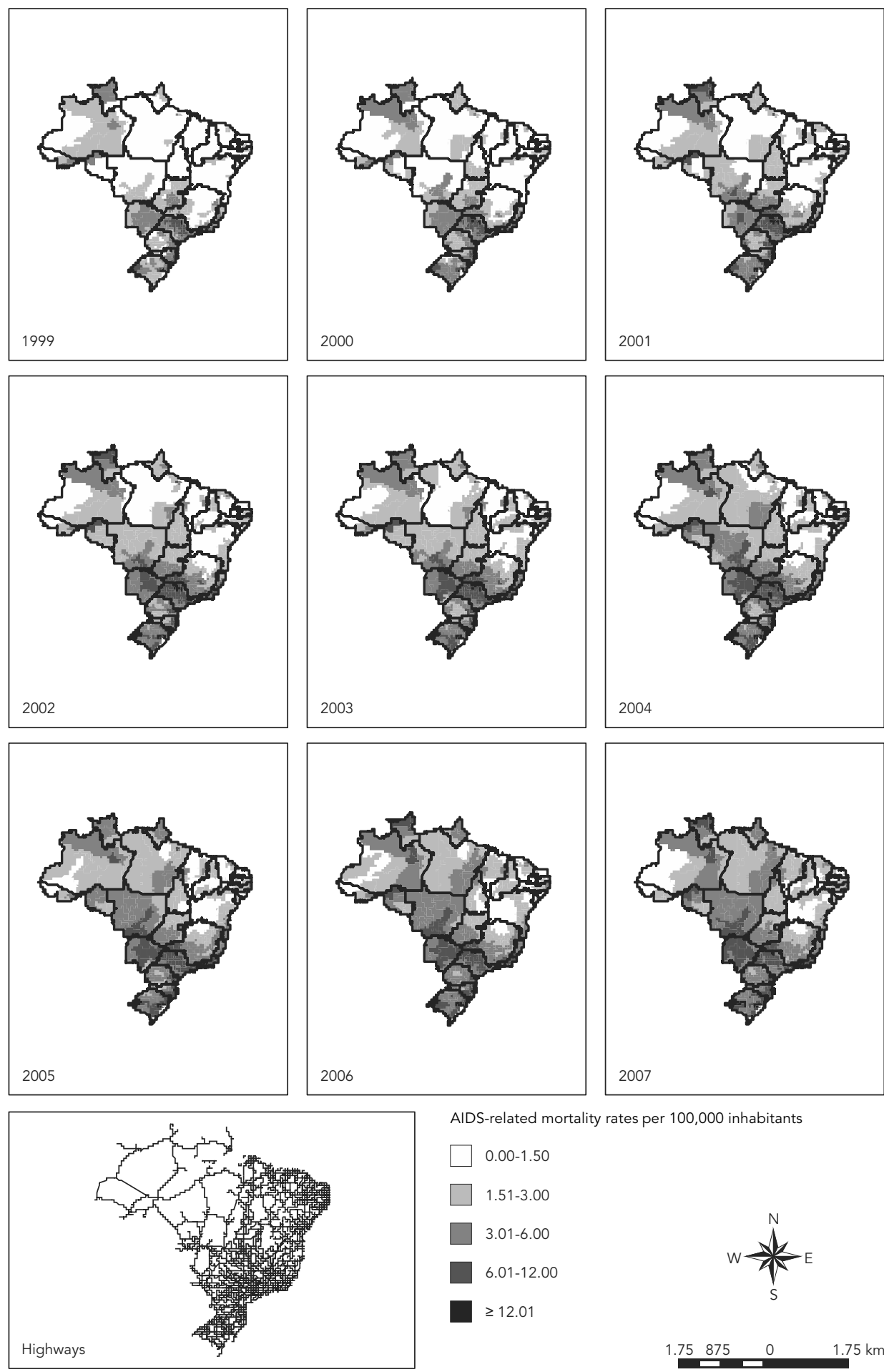

AIDS-related mortality rates per 100,000 inhabitants

$\square \quad 0.00-1.50$

$1.51-3.00$

$3.01-6.00$

$6.01-12.00$

$\geq 12.01$

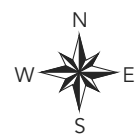

Note: data source, Information System on Diseases of Notification (SINAN. Information Technology Department of the Brazilian Unified National Health System. http://www.datasus.gov.br); geographic databases of the Brazilian Institute of Geography and Statistics (IBGE. http://www.ibge.gov.br); maps constructed by the Geoprocessing Laboratory of the Institute of Scientific and Technological Communication and Information in Health of the Oswaldo Cruz Foundation (LabGeo - ICICT/Fiocruz). 
diseases and health threats, such as HIV transmission and violence, since they act as links between isolated locations 27 .

Studies since 1996 have shown a steady drop in AIDS mortality; the increase in AIDS incidence was not accompanied by a proportional increase in the number of deaths 8,10 . Meanwhile, the Southeast also showed a drop in incidence since 1998, although less sharp than the decrease in mortality 10 .

Free and universal access to HAART in Brazil have led to an increase in quality of life and survival 28 and minimization of economic losses, due to the decrease in AIDS-related deaths, hospitalizations, and high-cost, high-complexity clinical and laboratory procedures 29,30.

An extensive literature review from 1996 to 200631 revealed a profound transformation in the AIDS epidemic in the post-HAART period, with a considerable increase in survival and quality of life and a major reduction in opportunistic infections.

According to the current study's findings, Brazil experienced an increase in the AIDS mortality rate from 4.38 to 6.13 deaths/100,000 inhabitants, from 1999 to 2007. There was no decline in AIDS mortality for the country as a whole, but the increase was slight. AIDS mortality only declined in the Southeast, while in the other regions the rates continue to increase, demonstrating that universal access and increased survival are not occurring in all cities of Brazil.

More than 25 years into the epidemic, Brazil has continued to experience a concentrated epidemic, with less than $1 \%$ prevalence of HIV infection in the overall population and declining incidence in most regions of the country, especially the Southeast. However, disparities between socioeconomic groups and regions pose challenges for the implementation of free and universal access to health services, including the follow-up and treatment of persons living with HIV/AIDS 5,32.

Our study also revealed regional disparities, since the drop in incidence in the Southeast, South, and Central-West was totally opposite to the sharp increase in rates in the North and Northeast. Meanwhile there was no decline in mortality, except in the Southeast.

One limitation to this study involved problems with underreporting and delayed recording of AIDS cases, common difficulties identified with diseases of mandatory notification in general. A study of data from the city of Rio de Janeiro in 1996 found $34.8 \%$ underreporting for patients using hospitals under the SUS for AIDS treatment, thus detecting an obvious mismatch between patient care and epidemiological surveillance 33 .
According to a recent study 34 , AIDS mortality in Brazil is also underreported and thus underestimated by the SIM. Five causes of HIV/AIDS-related deaths that presented classification errors were identified: pneumonia, Kaposi's sarcoma, other immunodeficiencies, other causes of septicemia, and other causes of pneumonia. Within the study's time frame, from 1985 to $2009,72,210$ AIDS deaths were recoded, representing $27 \%$ of classification errors for AIDS deaths in Brazil. However, notwithstanding the impact of underreporting, another recent study 35 identified a significant decrease in mortality for persons living with HIV/AIDS in follow-up from 1986 to 2009 in a referral hospital in Rio de Janeiro. According to a study by Grinsztejn et al. 35 with data from an HIV/AIDS treatment referral center, mortality from AIDS-related causes decreased from $9.19 / 100$ person-years in $1986-1991$ to $1.35 / 100$ person-years in 2007-2009; meanwhile mortality from causes unrelated to AIDS remained constant throughout the follow-up, at around 1/100 person-years.

Inconsistencies and gaps in the different databases highlight the need for linkage, a strategy that does not eliminate such limitations of secondary databases, but does minimize them.

Importantly, Brazil is a country with great demographic, cultural, and economic heterogeneity, a factor that can make the interpretation of nationally aggregated data imprecise and potentially biased, since such data are always heavily influenced by the Southeast, the region of the country with the largest population. The Southeast also boasts the country's greatest economic weight and dynamics, defined as an attractor and transit hub for persons and a wide variety of goods, with a decisive contribution to the establishment of social interaction networks from a broad range of perspectives, including the spread of communicable diseases.

Regional disparities in AIDS distribution in Brazil can be understood in light of the more recent introduction of the epidemic in the CentralWest and North, through migratory flows, shifting labor, and cargo transportation. Also important is the heterogeneity in the quality of healthcare and the development of information systems in different regions of the country. Such problems directly impact the quality of care for persons with HIV/AIDS and the trustworthiness of data in such systems, thus emphasizing the importance of better technical training for healthcare workers for such purposes, in-service training, and permanent data verification as part of a continuous process in the national information systems.

Public AIDS prevention policies should be targeted and adjusted according to the epidemi- 
ological profile of the municipalities and microregions, prioritizing those with the greatest magnitude of the disease.

This study showed that the apparent overall stabilization of the AIDS epidemic tends to mask regional disparities and the susceptibility of given specific locations and should thus be evaluated carefully through analyses with lower levels of aggregation such as municipalities and micro-regions.

\section{Resumen}

La disminución y estabilización de la epidemia de SIDA en Brasil deben ser consideradas con prudencia, ya que, en un país grande y diverso, los datos agregados pueden ocultar desigualdades regionales pronunciadas. El estudio reevaluó la difusión espacial de la epidemia y las muertes secundarias por SIDA. Se consideraron todos los casos diagnosticados con 18+años, residentes en Brasil, así como las muertes registradas en 1998-2008. Se estimaran las tasas medias móviles desde hace tres años y se llevó a cabo el análisis espacial a través del método bayesiano empírico local. La epidemia estaba en expansión en el Norte y Noreste, mientras que se redujo en el resto del país, en especial en el Sureste. Los análisis subrayan que la aparente estabilización de la mortalidad por SIDA oculta disparidades regionales. Los determinantes sociales de la salud y las disparidades regionales son claves en la formulación de programas y políticas públicas en Brasil.

Síndrome de Imunodeficiencia Adquirida; Análisis Espacial; Estudios Ecológicos

\section{Contributors}

T. R. A. Teixeira participated in the definition of the methodological design, literature review, data processing and analysis, discussion of the results, elaboration of the article, and final version. R. Gracie collaborated in the definition of the methodological design, data processing and analysis, and revision of the results. M. S. Malta contributed to the definition of the methodological design, data collection, and discussion of the results. F. I. Bastos participated in the definition of the methodological design, discussion of the results, and revision of the final version.

\section{Acknowledgments}

The authors wish to thank the Department of STDs, AIDS, and Viral Hepatitides of the Brazilian Ministry of Health for generously allowing use of the data for this article and the Graduate Studies Program of the Sergio Arouca National School of Public Health of the Oswaldo Cruz Foundation (ENSP/Fiocruz) for the opportunities for learning and professional growth provided by the doctoral course in epidemiology. Additional acknowledgements to FIOTEC for the funding. We thank Capes/Science without Borders Project for its support (grant 61/2011) 


\section{References}

1. Joint United Nations Programme on HIV/AIDS. AIDS report on the global AIDS epidemic. Geneva: Joint United Nations Programme on HIV/AIDS; 2012.

2. Malta M, Magnanini MMF, Mello MB, Pascom ARP, Linhares Y, Bastos FI. HIV prevalence among female sex workers, drug users and men who have sex with men in Brazil: a systematic review and meta-analysis. BMC Public Health 2010; 10:317.

3. Departamento de DST, Aids e Hepatites Virais, Secretaria de Vigilância em Saúde, Ministério da Saúde. Boletim Epidemiológico Aids e DST 2012; Ano I, no 1 .

4. Dias PRTP, Nobre FF. Análise dos padrões de difusão espacial dos casos de AIDS por estados brasileiros. Cad Saúde Pública 2001; 17:1173-87.

5. Bastos FI, Nunn A, Hacker MA, Malta M, Szwarcwald CL. AIDS in Brazil: the challenge and the response. In: Celentano DD, Beyrer C, editors. Public health aspects of HIV/AIDS in low and middle income countries. New York: Springer Science; 2008. p. 629-54.

6. Szwarcwald CL, Bastos FI, Andrade CLT, Castilho EA. AIDS: o mapa ecológico do Brasil, 1982-1994. In: Chequer PN, Medeiros MG, organizadores. Epidemia de AIDS no Brasil: situações e tendências. Brasília: Coordenação Nacional de DST e AIDS, Secretaria de Projetos Especiais de Saúde, Ministério da Saúde; 1997. p. 27-44.

7. Bastos FI, Telles PR, Castilho EA, Barcellos C. A epidemia de AIDS no Brasil. In: Minayo MCS, organizadora. Os muitos Brasis: saúde e população na década de 80. São Paulo: Editora Hucitec/Rio de Janeiro: ABRASCO; 1995. p. 245-68.

8. Grangeiro A, Escuder MML, Castilho EA. Magnitude e tendência da epidemia de AIDS em municípios brasileiros de 2002-2006. Rev Saúde Pública 2010; 44:430-40.

9. Marins JR, Jamal LF, Chen SY, Barros MB, Hudes ES, Barbosa AA, et al. Dramatic improvement in survival among adult Brazilian AIDS patients. AIDS 2003; 17:1675-82.

10. Dourado I, Veras MASM, Barreira D, Brito AM. Tendências da epidemia de Aids no Brasil após a terapia antirretroviral. Rev Saúde Pública 2006; 40 Suppl:9-17.

11. Malta M, Bastos FI, Silva CM, Pereira GF, Lucena FF, Fonseca MG, et al. Differential survival benefit of universal HAART access in Brazil: a nation-wide comparison of injecting drug users versus men who have sex with men. J Acquir Immune Defic Syndr 2009; 52:629-35.

12. Wood E, Montaner JS, Bangsberg DR, Tyndall MW, Strathdee SA, O'Shaughnessy MV, et al. Expanding access to HIV antiretroviral therapy among marginalized populations in the developed world. AIDS 2003; 17:2419-27.
13. Floyd S, Marston M, Baisley K, Wringe A, Herbst K, Chihana $\mathrm{M}$, et al. The effect of antiretroviral therapy provision on all-cause, AIDS and non-AIDS mortality at the population level: a comparative analysis of data from four settings in Southern and East Africa. Trop Med Int Health 2012; 17:e84-93.

14. Nunn AS, Fonseca EM, Bastos FI, Gruskin S. AIDS treatment in Brazil: impacts and challenges. Health Aff (Millwood) 2009; 28:1103-13.

15. Grangeiro A. O perfil socioeconômico dos casos de AIDS na cidade de São Paulo. In: Parker R, Bastos C, Galvão J, Pedrosa JS, organizadores. A AIDS no Brasil. Rio de Janeiro: Editora Relume-Dumará/ Associação Brasileira Interdisciplinar de AIDS/Instituto de Medicina Social, Universidade do Estado do Rio de Janeiro; 1994. p. 91-125.

16. Bastos FI, Barcellos C. Geografia social da AIDS no Brasil. Rev Saúde Pública 1995; 29:52-62.

17. Barcellos C, Bastos FI. Redes sociais e difusão da AIDS no Brasil. Bol Oficina Sanit Panam 1996; 121:11-24.

18. Szwarcwald CL, Bastos FI, Esteves MAP, Andrade CLT. A disseminação da epidemia de AIDS no Brasil no período de 1987-1996: uma análise espacial. Cad Saúde Pública 2000; 16 Suppl 1:7-19.

19. Szwarcwald CL, Bastos FI, Barcellos C, Esteves MAP, Castilho EA. Dinâmica da epidemia de AIDS no município do Rio de Janeiro de 1988-1996: uma aplicação de análise estatística espaço-temporal. Cad Saúde Pública 2001; 17:1123-40.

20. Fonseca MGP, Szwarcwald CL, Bastos FI. Análise sociodemográfica da epidemia de Aids no Brasil, 1989-1997. Rev Saúde Pública 2002; 36:678-85.

21. Fonseca MGP, Travassos C, Bastos FI, Silva NV, Szwarcwald CL. Distribuição social da AIDS no Brasil, segundo participação no mercado de trabalho, ocupação e status sócio-econômico dos casos de 1987 a 1998. Cad Saúde Pública 2003; 19: 1351-63.

22. Coordenação Nacional de DST e AIDS, Ministério da Saúde. PCAP: pesquisa de conhecimento atitudes e práticas na população brasileira, 2004. Brasília: Ministério da Saúde; 2006.

23. Assunção RM. Estatística espacial com aplicações em epidemiologia, economia, sociologia. São Carlos: Associação Brasileira de Estatística; 2001.

24. Santos SM, Souza WV, organizadores. Estatística espacial para a saúde pública. v. 3. Brasília: Ministério da Saúde; 2006. (Série Capacitação e Atualização em Geoprocessamento em Saúde).

25. Szwarcwald CL, Barbosa Júnior A, Souza Júnior PR, Pascom AR, Esteves MA. Situação da AIDS no Brasil: uma análise de indicadores para o monitoramento da epidemia. In: Programa Nacional de DST e Aids, Secretaria de Vigilância em Saúde, Ministério da Saúde, organizador. MonitorAIDS: sistema de monitoramento de indicadores do Programa Nacional de DST e Aids (versão 1.0). Brasília: Ministério da Saúde; 2004. p. 69-101. 
26. Brito AM, Castilho EA, Szwarcwald CL. Regional patterns of the temporal evolution of the AIDS epidemic in Brazil following the introduction of antiretroviral therapy. Braz J Infect Dis 2005; 9:9-19.

27. Barcellos C, Feitosa P, Damacena GN, Andreazzi MA. Highways and outposts: economic development and health threats in the central Brazilian Amazon region. Int J Health Geogr 2010; 9:30.

28. Hacker MA, Petersen ML, Enriquez M, Bastos FI. Highly active antiretroviral therapy in Brazil: the challenge of universal access in a context of social inequality. Rev Panam Salud Pública 2004; 16 : 78-83.

29. Teixeira PR, Vitória MA, Barcarolo J. Antiretroviral treatment in resource-poor settings: the Brazilian experience. AIDS 2004; 18 Suppl 3:S5-7.

30. Chequer P, Cuchí P, Mazin R, García Calleja JM. Access to antiretroviral treatment in Latin American countries and the Caribbean. AIDS 2002; 16 Suppl 3:S50-7.

31. Hacker MA, Kaida A, Hogg RS, Bastos FI. The first ten years: achievements and challenges of the Brazilian program of universal access to HIV/AIDS comprehensive management and care, 1996-2006. Cad Saúde Pública 2007; 23 Suppl 3:S345-59.
32. Fonseca MGP, Bastos FI. Twenty-five years of the AIDS epidemic in Brazil: principal epidemiological findings, 1980-2005. Cad Saúde Pública 2007; 23 Suppl 3:S333-44

33. Ferreira VMB, Portela MC, Vasconcellos MTL. Fatores associados à subnotificação de pacientes com AIDS, no Rio de Janeiro, RJ, 1996. Rev Saúde Pública 2000; 34:170-7.

34. Fazito E, Cuchi P, Fat DM, Ghys PD, Pereira MG, Vasconcelos AM, et al. Identifying and quantifying misclassified and under-reported AIDS deaths in Brazil: a retrospective analysis from 1985 to 2009. Sex Transm Infect 2012; 88 Suppl 2:i86-94.

35. Grinsztejn B, Luz PM, Pacheco AG, Santos DV, Velasque L, Moreira RI, et al. Changing mortality profile among HIV-infected patients in Rio de Janeiro, Brazil: shifting from AIDS to non-AIDS related conditions in the HAART era. PLoS One 2013; 8:e59768.

Submitted on 08/Mar/2013

Final version resubmitted on 25/Jun/2013

Approved on 14/Aug/2013 